\title{
At Rest
}

National Cancer Institute

\section{Source}

National Cancer Institute. At Rest. NCI Thesaurus. Code C64920.

A period of being still or inactive. 